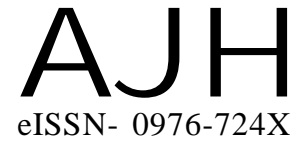

Article history :

Received : 24.12 .2015

Revised : 15.05.2016

Accepted : 22.05.2016

Members of the Research Forum

Associated Authors:

${ }^{1}$ Department of Horticulture, S.K.N.

College of Agriculture, JOBNER

(RAJASTHAN) INDIA

Author for correspondence :

A.K. SONI

Department of Horticulture, S.K.N.

College of Agriculture, JOBNER

(RAJASTHAN) INDIA
THEASIAN JOURNALOF HORTICULTURE

Volume 11 | Issue 1 | June, 2016 | 199-201

Visit us -www.researchjournal.co.in

\title{
Response of integrated nutrient management on the growth, yield and quality of Kharif onion (Allium cepa L.)
}

\section{A.K. SONI, R.S. DHAKA ${ }^{1}$ AND R. PALIWAL ${ }^{1}$}

ABSTRACT : The field experiment of study the "Effect of fertility levels on growth, yield and quality of Kharif onion" was conducted at Horticulture farm, S.K.N. College of Agriculture, Jobner during Kharif 2001 and 2002. The experiment comprising 8 fertility levels (Control, 75\%, $100 \%$ and $125 \%$ ) recommended dose of NPK vermicompost $2.5 \mathrm{t} \mathrm{ha}^{-1}$ with 25 per cent, 50 per cent and 75 per cent recommended dose of NPK. The application of 50 per cent recommended dose of NPK + vermicompost $2.5 \mathrm{tha}^{-1}$ significantly improved the plant height, number of leaves at harvest, equatorial diameter thickness of scale, volume of bulb, yield and TSS, vitamin "C" and allyl propyl disulphide content.

KEY WORDS : Recommended dose of NPK, Vermicompost, Yield

HOW TO CITE THIS ARTICLE : Soni, A.K., Dhaka, R.S. and Paliwal, R. (2016). Response of integrated nutrient management on the growth, yield and quality of Kharif onion (Allium cepa L.). Asian J. Hort., 11(1) : 199-201, DOI : 10.15740/HAS/TAJH/11.1/199-201. 